\title{
A Critical Analysis of the Protection of Stakeholders' Interests under the South African Companies Act: (Part 1)
}

\author{
Linda Muswaka \\ Faculty of Law, North West University, South Africa \\ E-mail: leemuswaka@gmail.com
}

Doi:10.5901/mjss.2014.v5n3p61

Abstract

Traditional company law enabled companies to embark on the 'shareholder value oriented approach,' the main focus being on the owners of equity. In terms of this shareholder value approach, the interests of the shareholders are paramount and interests of other stakeholders are considered only if their advancement will lead to shareholder value maximization, that is, 'through the prism of shareholder profit maximization.' Thus, the emphasis, in accordance with traditional company law, has been on the role of directors in managing and overseeing the company's business primarily for the benefit of the shareholders. Most of the checks and balances on the powers of the directors were aimed at considering, primarily one interest group, namely shareholders of the company. There has, however, been a shift in public opinion towards the recognition of a variety of interests that should be considered wider than only those of the shareholders. The wider variety of interests includes environmental concerns and the interests of stakeholders such as employees, suppliers, consumers and the community. This paper provides a critical analysis of the protection of stakeholders' interests under the Companies Act, 2008. The main concern is whether the Companies Act adequately protects the interests of stakeholders. The paper concludes that even though efforts has been made in the Companies Act 2008 to ensure that other stakeholders, apart from just shareholders are protected, it seems that legislation is far from effectively providing for the rights of stakeholders. In this regard, recommendations for law reform are made

Keywords: Corporate Governance, Shareholders, Stakeholders, Directors

\section{Introduction}

Traditional company law enabled companies to embark on the 'shareholder value oriented approach,' the main focus being on the owners of equity. In terms of this shareholder value approach, the interests of the shareholders are paramount and interests of other stakeholders are considered only if their advancement will lead to shareholder value maximization, that is, 'through the prism of shareholder profit maximization.' There has, however, been a shift in public opinion towards the recognition of a variety of interests that should be considered wider than only those of the shareholders. The wider variety of interests includes environmental concerns and the interests of stakeholders such as employees, suppliers, consumers and the community. This paper provides a critical analysis of the protection of stakeholders' interests under the Companies Act, 2008. The Companies Act was assented to by the President on 9 April 2009 and became effective on 1 May 2011. The Act deals in Chapter 2 with the formation, administration and dissolution of companies. Part $\mathrm{F}$ of Chapter 2 deals with the governance of companies. It introduces a number of provisions relating to the standards of conduct of directors. These include a partial codification of the common law duties of directors. This means that the Companies Act does not replace the common law duties of directors that are not expressly amended or are not in conflict with it. The main concern in this paper is whether the Companies Act adequately protects the interests of stakeholders. It will be argued that stakeholders' interests are best protected where an explicit duty exists for directors to consider the interests of other stakeholders. A call for law reform is therefore made in this regard.

\section{The Recognition of Stakeholder Interests under the Act}

With regard to the recognition of stakeholder interests under the Companies Act, section 76(3)(b) is important as it highlights the interests to be considered by directors when managing their companies. ${ }^{1}$ Section $76(3)(b)$ provides that

\footnotetext{
1 The provision deals with the directors' fiduciary duty to act in the best interests of the company.
} 
'directors must exercise their powers and perform the functions of director in the best interests of the company.'2 However, what is meant by 'the best interests of the company' is not defined. As a result, there is no clarity on whether or not directors should promote the interests of shareholders collectively, to the exclusion of the interests of the various stakeholders that have an interest in the company or whether broader interests should be promoted?' This issues emanate from the fact that the phrase 'the best interests of the company' in section 76(3)(b) of the Companies Act is not defined. As a result, guidance must therefore be sought from the common law as there can be found vast authority as to the meaning of this phrase. In Greenhalgh v Ardernie Cinemas $L t d$ ' the court stated that the phrase 'company as a whole' does not mean the commercial entity as distinct from the shareholders. It means the shareholders or incorporators as a general body. Thus, at common law, the phrase 'the best interests of the company' has generally been interpreted to mean the interests of the shareholders collectively, that is, 'all the shareholders, present and future. ${ }^{4}$ Hence, Cassim et al state that the word 'company' in the context of section 76(3)(b) is merely a synonym for the shareholders of the company. ${ }^{5}$ In this light, one may argue that the Companies Act is shareholder value oriented and that stakeholder interests are therefore not protected. In terms of the shareholder value approach a director has no general duty to consider the interests of stakeholders. Obviously directors are allowed to consider the interests of stakeholders and sometimes good management will require this, but ultimately the interests of stakeholders are subordinate to those of the shareholders.

It is in this regard that it is argued that section 76(3)(b) of the Companies Act should have been framed in ways that clearly indicate that directors must now take cognizance of the interests of stakeholders when managing their companies. What is clear currently, is that in light of section 76(3)(b), the duty of directors to act in the best interest of the company has become mandatory but at the same time still keeping to its common-law foundation. With this section, it can be viewed that South African company law prefers the shareholder value approach. The result of this is that where shareholders have received recognition, the interests of stakeholders have received no formal, legal recognition, exceptions that can be debated to be found in provisions of the Companies Act discussed below.

\section{An Analysis of the Stakeholder Oriented Provisions}

Section 20(4) of the Act provides that shareholders, directors and prescribed officers or a trade union representing employees may take proceedings to restrain a company from doing anything inconsistent with the Act. While in terms of this section, the persons who may take proceedings are restricted to shareholders, directors and prescribed officers or a trade union representing employees, section 157 provides for "extended standing to apply for remedies." It provides that when, in terms of the Act, an application can be made to, or a matter can be brought before, a court, the Companies Tribunal, the Panel or the Commission, the right to make the application or bring the matter may be exercised by a person inter alia acting as a member of, or in the interest of, a group or class of affected persons or acting in the public interest, with leave of the court. ${ }^{6}$ The scope of persons who can bring an application or a matter before the courts, Companies Tribunal or the Commission has therefore been widened by the Act.

In light of section 20(4) read with section 157(1) any interested stakeholder of the company may institute proceedings to restrain a company from doing anything inconsistent with the Act. However, it is questionable whether

\footnotetext{
2 In terms of section 77(2)(a), a director may be held liable in accordance with the principles of the common law relating to breach of a fiduciary duty, for any loss or damages sustained by the company as a result of a breach of inter alia, the duty to act in the best interest of the company. For a discussion of breach of a fiduciary duty see Havenga M "Breach of Directors' Fiduciary Duties: Liability on What Basis?" 1996 SA Merc LJ 366; Havenga M “Directors' Fiduciary Duties under Our Future Company-Law Regime" 1997 SA Merc LJ 310; Havenga M "Directors' Secret Profit - Accounting To the Company" 1991 SA Merc LJ 95; Havenga M "Directors in Competition with Their Companies" (2004) 16 SA Merc LJ 275; Cilliers et al Corporate Law (2000) 152; Farrar, Furey and Hannigan Company Law (1991) 396-402; Gower Modern Company Law (1992) 585-589; McLennan JS "Directors' Fiduciary Duties and the Companies Act" 1983 SALJ 417; McLennan JS "Directors' Fiduciary Duties and Misapplication of Company Funds" 1982 SALJ 394; Botha DH "Holding and Subsidiary Companies: Fiduciary Duties of Directors" 1984 De Jure 167.

${ }^{3}$ Greenhalgh v Ardernie Cinemas Ltd 1951 Ch 286291.

${ }^{4}$ See for example Havenga M, "Directors' Fiduciary Duties Under Our Future Company-Law Review" (1997) 9 SA Merc LJ 310; See also Cilliers et al Corporate Law 139- 140; Farrar JH, Furey N and Hannigan B Farrar's Company Law 709; Davies PL, Gower and Davies' Principles of Modern Company Law 2008 371; Mongalo T "The Emergence of Corporate Governance as A Fundamental Research Topic In South Africa" (2003) 120 SALJ 173 176-177. See also Percival v Wright 19022 Ch 421 424; Sibex Construction (SA) (Pty) Ltd v Injectaseal CC 19882 SA 54 (T) 65; Novick v Comair Holdings Ltd 19792 SA 116 (W) 130151.

${ }^{5}$ Cassim FHI, Cassim MF, Cassim R, Jooste R, Shev J and Yeats J Contemporary Company Law 2011 18-19.

${ }^{6}$ Section 157(1).
} 
section 20(4) read with section 157(1) would be effective in safeguarding the interests of stakeholders. This is because in the event of a conflict or dispute as to whether a director's failure to consider stakeholders' interests would render his conduct inconsistent with the Act, his conduct will be measured against section 76(3)(b).In this light, the right in terms of section 20(4) read with section 157(1) is thus not with regard to the interests of the stakeholders but is with regard to the interests of the company.

Another relevant provision that is stakeholder oriented is section 165(2) of the Companies Act. The section provides for the statutory derivative action. ${ }^{7}$ The statutory derivative action allows certain specified persons to institute proceedings on behalf of a company where the company has been prejudiced by acts of its controlling directors and where the company has failed to take the necessary action to call these directors to account. Section 165(2) provides that the persons who may use the statutory derivative action are (essentially) a shareholder, a director, a representative of employees or any other person with leave of the court. ${ }^{8}$ Section 165(2)(d) provides that a person may serve a demand upon a company to commence or continue legal proceedings or to take related steps, to protect the legal interests of the company if the person has been granted leave of the court to do so. However, such granting of locus standi to other stakeholders is left to the discretion of the court. Ultimately, if the stakeholders can prove to the court's satisfaction that they have locus standi to bring a demand to institute a derivative action and that it is the best interests of the company to do so, then such court has no other alternative but to grant such leave. However, a court will only grant such leave upon compliance by the company with one of the factors stated in section 165(5) of the Companies Act.

In light of this probable recognition of other stakeholders, it must not be forgotten that the ultimate purpose of the derivative action is to protect the legal interests of the company and not the legal rights of other stakeholders. As Cassim et al contend, the intention of section 165 may be to allow courts to grant standing to stakeholders whose legal rights are indirectly affected due to an infringement of the company's legal interests. ${ }^{9}$ Section $165(2)$ (d) allows the possibility of legal recognition for stakeholders' rights, including effective enforcement of such rights should they prove to have locus standi. If such standing is successfully proved and depending on the discretion of the court, then stakeholders can be said to have an effective action against management if their rights have been prejudiced. However, as mentioned, it must be kept in mind that the purpose of the statutory derivative action is to provide for the interests of the company and not the interests of the stakeholders.

Section 218 of the Companies Act dealing with civil actions is also relevant to the issue of the protection of stakeholder interests. In particular, section 218(2) provides that 'any person who contravenes any provision of this Act is liable to any other person for any loss or damage suffered by that person as a result of that contravention.' In light of this section, stakeholders can therefore argue that by not considering their specific interests, directors did not act in the best interests of the company. This will, however, be hard to prove as the third party will have to show that by not acting in his or her best interest the director did not act in the best interest of the company.

\section{Findings}

Even though in the Companies Act 2008 efforts has been made to ensure that other stakeholders, apart from just shareholders are protected, it seems that legislation is far from effectively providing for such rights. As has been highlighted, while various provisions in the Companies Act appear to be stakeholder oriented, the Act does not adequately protect stakeholders' interests as no direct rights are given stakeholders. The shortcoming of the Companies Act is that it largely excludes from explicit consideration the interests of other stakeholders such as employees, customers, creditors, the state and communities within which companies operate. It imposes on directors no affirmative obligation to consider the interests of other stakeholders. Protection of stakeholder interests therefore is left almost entirely to forces outside of company law. Furthermore, the current wording of section 76(3)(b) creates the impression that shareholder primacy is still preferred. In light of these findings, the following recommendations are made.

\footnotetext{
${ }^{7}$ See generally the following cases that shed light on the derivative action; Foss v Harbottle 18432 Hare 461; McLelland v Hulett 1992 (1) SA 456 (D); and Thurgood v Dirk Kruger Traders (Pty) Ltd 1990 (2) SA 44 (E).

8 See further section 165(2) read with section 157(3) and 165(16) of the Companies Act.

${ }^{9}$ Cassim FHI, Cassim MF, Cassim R, Jooste R, Shev J and Yeats J Contemporary Company Law 2011703.
} 


\section{Recommendations}

\subsection{Section 76(3)(b) of the Companies Act be Amended to Reflect the Stakeholder Approach}

Section 76(3)(b) of the Companies Act should have been framed in ways that clearly indicates that directors must now take cognizance of the interests of stakeholders when managing their companies. In this regard, it is recommended that the section be amended to read that "a director of a company, when acting in that capacity, must exercise the powers and perform the functions of director in the best interests of the company and all key stakeholders."

The above recommendation necessitates a further amendment to section 76(4) which deals with the business judgment rule and is closely linked to section 76(3)(b) and (c). In this regard, the following recommendation is made.

\subsection{Section 76(4)(a)(iii) of the Companies Act be Amended to Reflect the Stakeholder Approach}

In order to be in line with the above recommended amendment to section 76(3)(b), it is recommended that section 76(4)(a)(iii) be amended as follows: "In respect of any particular matter arising in the exercise of the powers or the performance of the functions of director, a particular director of a company- (a) will have satisfied the obligations of subsection (3)(b) and (c) if-... (iii) the director made a decision, or supported the decision of a committee or the board, with regard to that matter, and the director had a rational basis for believing, and did believe, that the decision was in the best interests of the company and all key stakeholders; and ..."

The proposed amendments to sections 76(3)(b) and 76(4)(a)(iii) will clarify the position of directors with regard to key stakeholders. They make it clear that directors have a fiduciary duty to consider the interests of the company as well as those of all key stakeholders. However, a question that may arise is what is meant by 'key stakeholders.' In this light the following recommendation is made.

\subsection{Section 1 of the Companies Act Include a definition of 'key stakeholders.'}

It has been recommended that the Companies Act imposes a duty on directors to consider the interests not of all stakeholders, but of all key stakeholders. It is recommended that section 1 include the following definition for key stakeholders: "For purposes of this Act (Companies Act) the term 'key stakeholders' shall refer to stakeholders collectively, with legitimate interests in the business - stakeholders that merit and receive consideration in business decisions."

Each company will have a different set of stakeholders, depending on its core business. A socially responsible business should attend to the legitimate interests of all of its stakeholders and act in the interest of all of the stakeholders, not just the shareholders (who are also stakeholders). Stakeholders could include employees, local communities, the government, customers, and suppliers. A company may engage with stakeholders only if it has identified those stakeholders with legitimate interests in the business - stakeholders that merit and receive consideration in business decisions.

\subsection{Section 165(2) of the Companies Act be Amended to Reflect the Stakeholder Approach}

Section 165(2) provides for the statutory derivative action. The statutory derivative action allows certain specified persons to institute proceedings on behalf of a company where the company has been prejudiced by acts of its controlling directors and where the company has failed to take the necessary action to call these directors to account. The ultimate purpose of the statutory derivative action is to provide for the interests of the company and not the interests of the stakeholders. It is recommended that the purpose of the statutory derivative action should be broadened to also provide for the interests of the stakeholders. In this regard, the following amendment to section 165(2) is proposed: "A person may serve a demand upon a company to commence or continue legal proceedings, or take related steps, to protect the legal interests of the company and all key stakeholders if the person-..."

The above recommendation will provide stakeholders with a right of enforcement with regard to their own interests as well as opposed to only the interests of the company as is the case in the current wording of section 165. Furthermore, the proposed amendment will make it easier for the stakeholders to prove to the court's satisfaction that they have locus standi to bring a demand to institute a derivative action and that it is in the best interests of the company and all key stakeholders to do so. It is however noted that a court will only grant such leave upon compliance by the 
company with one of the factors stated in section 165(5) of the Companies Act.

\section{Conclusion}

While in the Companies Act attempts have been made to incorporate stakeholders' interests, shareholder interests still have primacy. As a result, the Companies Act can hardly be considered as a form of effective legal measure for stakeholders looking to uphold their rights due to its failure to provide an effective enforcement mechanism. Stakeholder provisions such as section 20(4) read with section 157(1) and section 165(2) are not at all effective in protecting stakeholder interests. In terms of section 20(4) read with section 157(1) any interested stakeholder of the company may institute proceedings to restrain a company from doing anything inconsistent with the Act. However, in the event of a dispute as to whether a director's failure to consider stakeholders' interests renders his conduct inconsistent with the Act, the director's conduct will be measured against section $76(3)(b)$. In this light, the effect of the provision is that it benefits the company and not the stakeholders. The derivative action provided for in section 165(2), despite its development from its common law origin, also fails to provide effectively for stakeholders as such action is ultimately for the benefit of the company and not the person instituting the action. It is in this regard that a call for law reform has been made.

\section{References}

Benade, M. L., J. J. Henning, J. J. Du Plessis, P. A. Delport, L. De Koker \& J. Pretorius (2008). Entrepreneurial Law. Special ed. Durban: LexisNexis.

Cassim FHI, Cassim MF, Cassim R, Jooste R, Shev J and Yeats J Contemporary Company Law 2011703.

Davies D, Cassim F, Geach W, Mongalo T, Butler D, Loubser A, Coetzee L and Burdett D, Companies and Other Business Structures in South Africa $2^{\text {nd }}$ Edition (2011) Oxford University Press Southern Africa.

Esser I, "A global perspective on African Corporate Governance: the protection of stakeholders' interests" (2007) 32 South African Yearbook of International Law: Good Governance \& Non-state Actors in International Law: an African Perspective: Regional Conference $406-429$

Esser I, "Stakeholder Protection: The Position of Employees" (2007) 70 TydskrifvirHedendaagseRomeins-HollandseReg 407.

Esser I, "The Protection of Stakeholder Interests in Terms of the South African King III Report on Corporate Governance: An Improvement on King II?" (2009) 21 SA Merc LJ 188-201.

Esser I and Dekker A, "The Dynamics in Corporate Governance in South Africa: Broad Based Black Economic Empowerment and the Enhancement of Good Corporate Principles" (2008) 3(3) J. of Int. Commercial Law and Technology 157.

Esser I and Du Plessis JJ, "The Stakeholder Debate and Directors' Fiduciary Duties" (2007) 19 SA Merc LJ 346.

Havenga M, "The Company, the Constitution and the Stakeholders" (1997) 5 Juta BusinessLaw Journal 134-139.

Hendrikse JW and Hefer-Hendrikse L Corporate Governance Handbook $2^{\text {nd }}$ Edition 2004 Juta\& Co. Ltd.

Ho VEH, "Enlightened Shareholder Value: Corporate Governance Beyond the Shareholder-Stakeholder Divide" 2010 36(1) The Journal of Corporation Law 59. 